\title{
Internationalization of Small and Medium Enterprises from Arusha Tanzania: Market Information, Financial Resources and Product Quality Setbacks
}

\author{
Liliane Pasape
}

Correspondence: Liliane Pasape, School of Business Studies and Humanities, Nelson Mandela African Institution of Science and Technology, Arusha, Tanzania.

Received: May 11, 2018

doi:10.11114/bms.v4i2.3268
Accepted: May 28, $2018 \quad$ Online Published: May 29, 2018

URL: https://doi.org/10.11114/bms.v4i2.3268

\begin{abstract}
The small and medium enterprises (SMEs) are key players towards reviving the economy and livelihood development in Tanzania, yet their involvement in international business is still unsatisfactory. This study therefore assessed the three major setbacks for industrialization of Arusha's SMEs namely as information, finance and quality. A cross-section research design was conducted using questionnaires. Through non-probability sampling, 50 respondents were stratified selected from SMEs owners, employees, business development support organizations and regulators. Data was analysed using descriptive statistics and logit model. The findings on the existing business environment revealed that: majority of the SMEs involve women (68\%) dealing with handcraft and tailoring, with less than five years of business experience. Moreover, the major identified information setbacks are low access to information source, use of irrelevancy market information, use of in effective medium of communication and high cost of the information. Besides, other financial related setbacks are limited sources of capital, lack of collateral, poor credibility history and high transaction cost. On quality setbacks include selling semi processed products, poor finished product and packaging materials as well insufficient processing machinery. Thus for SMEs internationalization the following recommendations are established: improving accessibility and affordability of relevant market information; designing various financial products at reasonable lending rates, strengthening entrepreneurial skills and formalization of enterprises; enhancing availability of processing machinery and packaging materials for improving product quality and competitiveness as well as avoiding selling of semi processed products . Above all, the government, regulators, private sector organizations and other key players along the value chain must play their respective relevant role towards supporting SMEs.
\end{abstract}

Keywords: SMEs, internationalization, finance, product quality, information, Arusha, Tanzania.

\section{Introduction}

The United Republic of Tanzania (URT) is the largest country in East Africa with an average economic growth of about 6 - 7\% (The World Bank, 2018). According to its Vision-2025, the URT envisions itself to have created a strong, diversified, resilient and competitive economy, which can effectively cope with the challenges of development and which can also easily and confidently adapt to the changing markets and technological conditions in the regional and global economy (URT Ministry of Industry Trade and Investment, 2003; URT Ministry of Finance, 2018). Attainment of this vision to large extent depends on private sector's role of creating incomes and employment simply because the small and medium enterprises (SMEs) account for a large share of the enterprises active in Tanzania. This economic growth will be, in large party, private-sector led because according to an investment website, the Tanzania Invest (2008), citing the Tanzania Chamber of Commerce, Industry and Agriculture reports that $95 \%$ of the businesses in Tanzania are small and Medium Enterprises (SMEs) and they represent about 35\% of the country's GDP. Thus SMEs are the driving engine behind economic growth (Ale Ebrahim, Ahmed, and Taha, 2009).

Over the years, the SMEs within the private sector have played a critical role in developing the Tanzanian economy through creation of employment opportunities, income generation and equitable distribution of income (Hamisi, 2011). Thus, as the nation strives to revive the economy and develop it people in totality, SMEs are one of the best options to start with. However, there is a general acceptance that the full potential of the SME sector has yet been tapped due to the existence of a number of constraints hampering the development of the sector (URT Ministry of Industry Trade and Investment , 2003). Apart from local operations, potentiality of SMEs can also be attained through internationalization 
of their busineses. Örberg Jensen, (2009) pointed out that most industries can adapt to and internationalize its whole or parts of its business processes, but to simplify they can be narrowed down in to two different categories namely manufacturing industry for physical produce products, standardized processes, such as phone or custom services, processes or tasks that can be solved without having a specific knowledge Various studies reviewed indicated that SMEs are facing some challenges in accessing global export markets mostly in developed world and internationalization of their business.. Compared to regional markets among Kenya, Uganda, Zambia, etc., these international markets in the developed world demand higher quality, timely delivery, and minimum consignment volume. Ale Ebrahim et al., (2009) depicted that while SMEs play a critical role in generating employment and supporting trade, they face numerous challenges, the prominent among them are the need to respond to fasting time-to-market, low-cost and rapid solutions to complex organizational problems. Besides, Kazimoto (2014) in his study on challenges facing SMEs towards international marketing standards reported that SME's are unaware of regulations and standards, they lack financial support from the Government, have poor understanding of consumer's needs and services, they lack essential entrepreneurial skills and posses weak networking structures to penetrate into international marketing. Among the most affected sector is agro business as evidenced in Caiazza (2016) that, in the agro-food industry, small and medium-sized enterprises (SMEs) are unable to internalize the global supply chain for exporting their products abroad.

In view of that, various efforts were taken by different regimes on reviving SME's industries and economic activities. Such efforts lead the government through Bank of Tanzania to initiate SME credit guarantee schemes, Mwananchi empowerment fund, national entrepreneurship development fund as evidenced in (URT Planning Commission Dar es Salaam and Regional Commissioner's Office Arusha, 2008). Facilitating the emergence of a vibrant small and medium sized enterprise (SME) sector is promoted as the new development prescription for low-income countries (Poole, 2008). Despite these efforts, Tanzania's SMEs are still weak and unable to stand up competitively against multinational companies for local, national, regional, and even global markets. Policy and approaches of harmonising, culturising, and diversifying SMEs are challenging because the content of the concept of amalgamating and moulding of socialism and self-reliance to market economy is unclear not only to small business entrepreneurs but also to policy-makers (Hamisi, 2011). In addition to that, Mpunga (2016) pointed out clearly that, the SMEs sector has tremendously expanded in Tanzania over the last three decades. Despite this expansion, it is unfortunate that most of the SMEs are focusing on the narrow domestic markets instead of exploring many opportunities found in international markets. This has resulted into low number of traders in the international market from Tanzania which is a motivation behind the current study to analyse what went wrong, how and why, using Arusha region as a focus area.

Arusha is found in northern Tanzania, it shares its northern border with the Republic of Kenya, the northeast of Arusha region borders with Kilimanjaro region, further east is Tanga region, to the south is capital city of Tanzania, Dodoma, to the west Shinyanga region is found and to the northwest Mara region. The population of Arusha region is 1,694,310 according to National census of 2012 and projection for 2017 is 1,943,196. The city hosts numerous small and large businesses, banking, retail and commercial enterprises thus making it the financial and cultural capital of the northern region of Tanzania. The city of Arusha is also a home to the largest manufacturing sector in the region with breweries, and agro-forest processing, and a large pharmaceuticals maker. Tourism is also a major part of the economy of Arusha, and the largest dollar-earning economic sector in Tanzania. This business and economic potential of Arusha was the motivation behind its being selected as a case study.

Research on the international activities of SME has been increasing in the recent years, foristance, Anderson (2011) conducted a survey in Tanzania on internationalization of SMEs; the results revealed the existing opportunities including export rehabilitation incentives, schemes as well as institutional supports granted from the governmental and nongovernmental organizations, development partners, and business associations. However, several limitations were pointed out including inadequate international business skills, unawareness of existing export promotion programs, finance accecibility, and imperfect foreign market information. The author concludes by drawing attention to managerial and policy implications and future research directions. The study capitalizes on Anderson's work by working further to assess specific setbacks and to what extent different variables of finance and market information affect SMEs internationalization. In another study, Mpunga (2016) assessed the export trade barriers among Tanzanian SMES. The findings show that SMEs owners' fear of export market was the most significant barrier, followed by the national business environments, and finally SMEs' export competencies. The article concludes that focusing on individual components in each of the three categories reveals no consistence within the classification where in all categories both very significant and relatively less significant barriers were. Thus, the study recommends specific and context sensitive analysis of export barriers. In that context this study opted to study further more significant barriers, including quality of the products in reration to its affect on price, taxes, accreditation, market certainty and financing opportunities. 
Rutashobya and Jaensson, (2004) pointed out that a number of theories have attempted to explain why, when, where, and how firms engage themselves in international business. They range from economic to behavioral theories. Economic theories that have been used range from those that explain why trade takes place between nations to theories of the firm that explain the economic logic of going international. On the other hand behavioral theories have their roots in business administration, and they focus on the managerial decisions of the individual firm or the owner manager. Despite those highlighted challenges, Dominguez and Mayrhoefer (2016) depicted that, the internationalization process of SMEs continues to follow several stages, but their commitment to foreign markets may increase, decrease and re-increase. The identified stages, which can be triggered by internal and external factors, reflect characteristics of different internationalization models. Along the same context Justin, Sundar and Parul (2017) wrote a review which serve as a basis to understand the research gaps, opportunities, and undertake new research projects based on the propositions and the future research agenda outline as far as internationalization of SMEs is concerned. However, more research is needed to clear the gaps, and so the current study aimed at assessing the SME's in Arusha relative to their involvement in the international markets using three main aspects of information, finance and product quality.

\subsection{Conceptual Framework}

With regard to conceptual framework, internationalization of SMEs is the function of three major variables namely; market information, quality of produce and adequate finance mathematically presented in equation 1 :

$$
\mathrm{Y}=\mathrm{f}(\mathrm{I}, \mathrm{Q} \text { and } \mathrm{A})
$$

Where:

$\mathrm{Y}=$ Internationalization of SMEs

$\mathrm{f}=$ function of

$\mathrm{I}=$ Information on international markets

$\mathrm{Q}=$ Quality of the product

$\mathrm{A}=$ Adequate financing for SMEs

\subsection{Objectives and Hypotheses}

The main objective of the study was to assess the major setback for internationalization of the Tanzanian SMEs. The specific objectives were as follows:

(i) To ascertain the role of relevant information in international market,

(ii) To determine the contribution of finance in the international market and

(iii) To determine the impact of SMEs quality of the products in international market.

In line with that, this study tested three hypotheses as follows:

H1: Market information gap has no significant impact in SMEs success to international markets;

H2: Financing shortage has no significant impact in the failure of SMEs in international markets

H3: Quality inconsistency has no significant impact in SMEs performance in international markets.

In order to test these hypotheses, the study considered several key sub-variables and assumptions under each hypothesis as follows:

- Market information gap: to establish where exactly SMEs get market information to assist decision making process, relevancy of the obtained or available information, medium of communication and cost of obtaining information. All these pieces of market information are crucial in setting up the marketing information system composed of people, equipment and procedures to gather, sort, analyses and distribute timely information that define and differentiate the value proposition and competitive advantage as depicted in Harmon (2003) and Kotler and Keller (2006)

- Adequate financing: capital availability, availability and type of collateral used to secure capital finance, the supporting history which would enhance SMEs credibility when approaching financial institutions and costs related to transactions. Sitorus (2017) pointed out that the SME sector comprises of enterprises with different characteristics. Common differentiating characters are size, sector, location, business life cycle, and ownership profile (gender, education, etc.). SMEs may have different needs for financial services and products according to their characteristics. In line with that, the World Trade Organization (2016) reported that the availability of finance is essential for a healthy trading system. Today, up to 80 per cent of global trade is supported by some sort of financing or credit insurance. However, there are significant gaps in provision and therefore many 
companies cannot access the financial tools that they need. The estimated value of unmet demand for trade finance in Africa is US\$ 120 billion (one-third of the continent's trade finance market) and US\$ 700 billion in developing Asia Small and medium sized enterprises (SMEs) face the greatest hurdles in accessing financing on affordable terms. This is of particular concern as SMEs are a leading driver of trade, employment and economic development.

- Quality inconsistency: selling semi processed or semi -finished product in relation to the product quality and value, poor finishing of the products, availability and price of both processing machinery and packaging materials. The justification for this is linked to Kalantone and Knight (2000) argument that a key lever in the success of any firm is product quality. While perhaps the most important single factor affecting business performance, quality's role in foreign markets has received little research attention. Besides, Singh (2013) reported that product quality is a vital area because it decides the market share of the firm. It is also used as one of the product differentiation strategy by few leading firms. Marketing has to set the quality standards for the firm's products.

\section{Method}

\subsection{Research Design}

The study employed a cross-section research design conducted through a questionnaire. The coverage was Arusha's SMEs focusing on handcraft and tailoring industry. The units of analysis were entrepreneurs, umbrella organization such as Small Industries Development Organization (SIDO), Centre for Agriculture Mechanization and Rural Technology (CARMATEC), Tanzania Chamber of Commerce, Industry and Agriculture (TCCIA), exporting department managers and owners and financial firms.

\subsection{Sampling Procedure}

The study applied non-probability or purposeful sampling to get respondents from populations in various areas of Arusha such as Mjini Kati, Sinoni, Sekei and Olasiti wards. Respondents were selected deliberately by the study to fulfill the objective. The study population was SME members who represent the huge number in the Arusha urban. Specifically, this study had a sample of 50 respondents who are members of SMEs representing 20 from the handcrafts, 20 from tailoring SMEs and sample that involve 5 staffs of CRDB, NMB and Equity Bank, SIDO, TEMDO, CARMATEC and 3 members from Arusha urban industrial marketing and cooperative officers as well as 2 members from Arusha regional business department. Thus stratified sampling was done from a list of SMEs found in the study area. The sample size fall within the minimum acceptable for non-probability sampling according to Saunders and Thornhill (2012).

\subsection{Data Collection}

During data collection, the researcher used both primary and secondary data. While the primary data were collected by the survey, secondary data were collected from earlier related studies. The questionnaire had both open-ended and closed which were designed in a manner that they reflected the research objectives and study research questions. The questionnaire was pretested before the actual application in this research. The collected data were entered into a database program and checked for the consistency to ensure that the statements given were not contradicting each other.

\subsection{Data Analysis}

Descriptive data analysis was done using the IBM SPSS Statistics. The analysis was conducted for three main areas namely as respondents characteristics, international market environment for Tanzanian SME's and three major setbacks for internationalization of Tanzania's SMEs namely as finance, product quality and market information. Besides, in order to establish cleary relationship of variables, the collected data were also analyzed using the following adopted estimated binomial logit regression model.

$$
\mathrm{P}(\text { AGREE}=\mathrm{i})=\exp (\mathrm{xi} \beta) / 1+\exp (\mathrm{xi} \beta)
$$

Whereby:

i. Information setback; $x i \beta=\beta_{0}+\beta_{1}$ source of information $+\beta_{2}$ relevancy of information $\beta_{2}$ medium of communication $+\beta_{2}$ cost of information $\sum_{j}^{i} \beta_{j} \mathrm{Zij}$

ii. Financial setback; $x i \beta=\beta_{0}+\beta_{1}$ capital $+\beta_{2}$ collateral $_{+}+\beta_{2}$ credibility history $+\beta_{2}$ transaction cost $+\sum_{j}^{i j} \beta_{j}$ Zij

iii. Quality of the product; $\mathrm{xi} \beta=\beta_{0}+\beta_{1}$ semi processed products $+\beta_{2}$ poor finishing $+\beta_{2}$ packaging materials $+\beta_{2}$ processing machinery $+\sum_{j}^{i} \beta_{j} Z_{i j}$

iv. zip $=$ the dummy variables,

v. $\beta 1$ and $\beta 2, \beta 3$ and $\beta 4=$ the regression coefficients 
Therefore AGREE I denotes the ith individual agree (AGREE $\mathrm{i}=1$ ) or not agree (AGREE $\mathrm{i}=0$ ) with the internationalization setbacks.

\section{Results and Discussion}

\subsection{Respondents Characteristics}

The study found 62 percent of the SME operators were female and 38 percent were males, implying that SME sector in Arusha SME sector in Arusha is a female to large extent. This is due to the social cultural settings of society of the northern Tanzania (Arusha, Kilimanjaro and Manyara) that women engage much in taking care of the family activities like farms and ensuring availability of food for the children while men engage on monitoring and security of the assets including gathering livestock etc. The findings also have been supported by Sitorus (2017) that Tanzania's SME sector consists of more than 3 million enterprises and most of them are in the agricultural sector, and more than half are owned by women. On aspect of age, it was established that 36 percent of the actors are aged between 36 to 45 years. It is the group which contains middle aged SME operators who are proactive and aggressive actors in competitiveness of the business as well as they are likely to increase the probability of formalizing their business as revealed in Ishengoma (2018). Also 22 percent of the respondents age between 26 to 35 years. This group contains most vibrant youths who have less experience in how well they can access information and finance issues. The other group of 46-55 years is 18 percent. This is experienced group who have ability and enough access to information, finance and know the quality that is supposed to go to market. The age group of 55 years and above is inactive but has everything it takes to go international. The first group of 25 years and below has little knowledge of importance of international market. The variation of the age has significant role to play in their business.

Besides, on education level, the study depicted that 44 percent were having ordinary level of secondary education, 28 primary level or below, 10 percent university while postgraduate or above level was 6 percent. The variation in education level contributed significantly in the performance of their business enterprise. Essays UK (2013) depicted that Tanzanian environment is quite different from that of western world where most of the entrepreneurship theories were formulated. For instance, the level of education is much lower in Tanzania than it is in the western world. In fact, it has been suggested that most of these firms are run by entrepreneurs who have a low level of education, and who depend on simple hand tools to make furniture. Moreover, the findings show that the income range to most SME is either or below the threshold that can be sufficient to most owners to sustain the business competition. This leads to most SMEs not to have relevant sources of information, lack of packaging materials, unable to finance their business and at the same time be weak in the market. Findings also shows 40 percent of the SMEs owners have minimum income of 750,000/= and only 4 percent have income of above 25,000,000/=. This tells us how weak our SMEs financial muscles are in domestic market which might also hold a true factor on the international business. The income for the SME range is not too convincing as $40 \%$ of the respondents have less competitive advantaged in even domestic market.

In addition to that, on aspect of role played by SMEs within the sub-sector, the research shows us that 48 percent of the interviewees were SMEs owners and 30 percent are people employed in the SME sector. This proves that SME is a vital engine to contribute to the national GDP of the any country. But also the 10 percent of the support organization helps us to understand the gap between the support organizations to SMEs while 5 percent of the regulatory bodies are subject to intensification of the proper administering of the SME sector. 2 percent is the representative of financial industry that deprived link to SME sector. This means there are huge potential left unsaved by various stakeholders that would improve SMEs potential to competitive in international markets.

\subsection{Major Setbacks for Internationalization of Tanzania's Smes}

In the process of assessing the international market environment for Tanzania SMEs, the study concentrated on five parameters known as: duration of SMEs in business, daring to access international market, prospects on handcraft and tailoring business, survival of SMEs in international market and government support to SMEs.On duration of SMEs in business, the researcher was inquisitive to know the time SME have been in business and the findings show that 48 percent of SMEs have been in business for between 1-3 years while 22 percent have been in business for 3-5 years. SME with time Less than 1 and more than 5 years were 16 to 14 percent respectful. This could indicates that majority of our SMEs (for over 70 percent) have less time in business (experience of below 5 years) and hence could cause them to be less competitive advantage in international market. Moreover, daring to access international market was set to establish the desire and ambition of SME to explore other markets in Africa or Europe. The results showed that 38 percent have daring mind to access the international market while 62 percent said no. This finding depicted that, despite of the existing opportunities in the internal national market, still large group of SME's are not ready to grab them, this might be attributed by a number of factors and challenges which will be discussed in details in the coming section of this study's findings. With respect to the prospects on handcraft and tailoring business, it was established that majority of interviewees agreed by 70 percent of the handcraft made in Arusha have quality and touch that could be taken to any 
market and sale with no problem. Only 30 percent disagreed with the handcraft and tailoring business. This assures the competitive position of Tanzania's SME's product in the market. Apart from that ssurvival of SME in international market was among the very interesting part of the research, the findings show that 72 percent of SME owners have strong belief that they can make to international arena but they fail to go due to lack of relevant information, finance being the major staple blocks as depicted in the Table 2. On the government support to SME, the findings depicted that the government has been supporting the SME business as evidenced in the statistics that 56 percent against 44 who answered that the government is not supportive. It is true that the governments has been supportive by setting up a number of organizations but with most of SME owner being lowly educated people have been taking advantage of that situation to bend the good course of the government in their favor. The detailed findings of the international market environment Tanzanian SMEs is shown in Table 1.

Table 1. International Market Environment for Tanzanian SME's

\begin{tabular}{lll}
\hline Aspect & Variable & Percent \\
\hline \multirow{2}{*}{ Duration of SMEs in International business } & Less than one year & 16 \\
& Between 1-3 years & 48 \\
& Between 3-5 years & 22 \\
Daring to access international market & More than 5 years & 14 \\
& Yes & 38 \\
Prospects on handcraft and tailoring business & No & 62 \\
\multirow{2}{*}{ Survival of SME in international market } & Agree & 70 \\
& Disagree & 30 \\
Government support to SME & Yes & 72 \\
& No & 28 \\
\hline
\end{tabular}

Source: field survey

\subsection{Major Setbacks to International Market}

\subsubsection{Role of Relevant Information in International Market}

The first study's objective to be tested was the role of relevant information in international market. The objective was addressed by four areas known as source, relevancy, medium and cost of the information. The findings (Figure 1) show that, for over $56 \%$ respondents agreed that information has a great role to play in international business. Specifically the findings revealed that costs of retrieving information is vital for $70 \%$ followed relevancy of information (66\%) source of information $(58 \%)$ and, medium of information $(56 \%)$

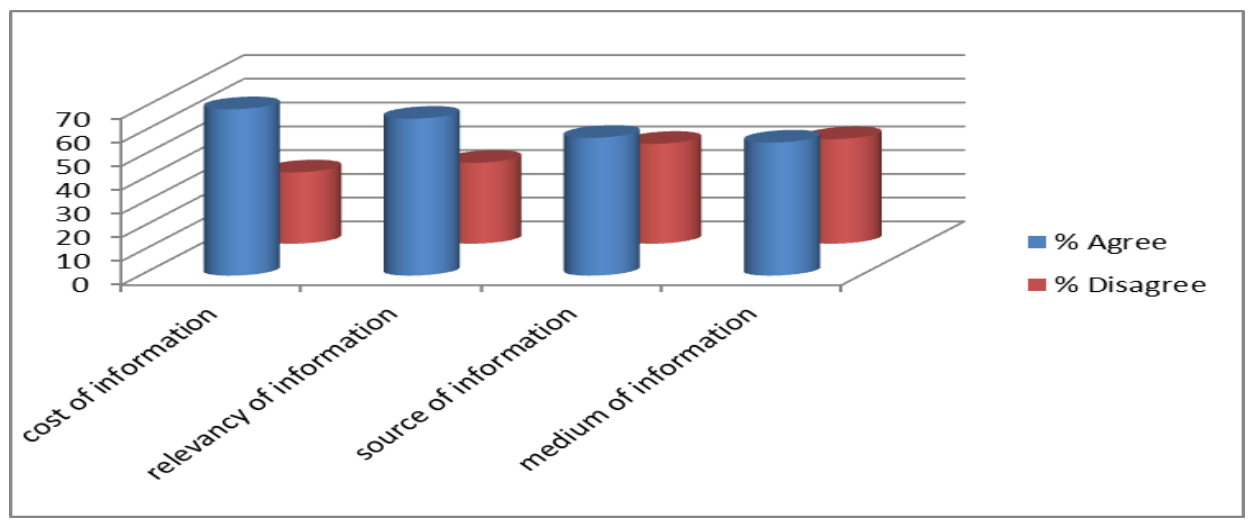

Source: Field data

Figure 1. Degree of agreement of the role of information in international marketing (in percentage \%)

In addition to descriptive analysis, logit regression analysis was employed to predict the probability that a participant would agree on the role of relevant information towards international market success. The predictor variables were the respondent's age, gender, education, income and role of which the findings (Table 2) reveal that the probability of the model to give the correct prediction relationship ranges from were 81, 66, 92 and 98 percent for information source, relevancy, medium and cost respectively. Besides that the ability of a logit regression model on satisfaction to account for variability in the dependent variable through cox \& snell's r-square was ranging between 67.2 and 72.3 percent. This implies that, most of the variability was encountered for over sixty percent. Moreover, the findings from the chi square 
analysis which tested the full model versus a model with intercept shows that all were statistically significant value of 0.00

Table 2. Change of internationalization setback with regard to change in respondents' variables

\begin{tabular}{lcccc}
\hline Variables & $\begin{array}{c}\text { Source of } \\
\text { Information }\end{array}$ & $\begin{array}{c}\text { Information of international market } \\
\text { Relevancy of } \\
\text { Information }\end{array}$ & $\begin{array}{l}\text { Medium of } \\
\text { Communication }\end{array}$ & $\begin{array}{l}\text { Cost of } \\
\text { Information }\end{array}$ \\
\hline $\mathrm{p}$-value & 0.00 & 0.00 & 0.00 & 0.00 \\
\hline $\mathrm{R}^{2}$ & $67.2 \%$ & $72.3 \%$ & $65.7 \%$ & $68.2 \% \mathrm{z}$ \\
\hline Regression & & & & \\
coefficient $(\beta)$ & 17.3 & -1.2 & -16.9 & -21 \\
Gender & 2.4 & 0.3 & 2.4 & 3.4 \\
Age & 3.5 & -0.4 & -3.6 & 15.9 \\
Education & 19.9 & 2.2 & 19.4 & 19.4 \\
Income & 18.5 & -0.6 & 19 & -0.8 \\
Role & & & & \\
\hline Source: & & & & \\
\hline
\end{tabular}

Source: Field data

Additionnally, Figure 2 shows that when holding all other variables constant, the variables which were most explained are income, role and gender. However, all of the independent variable influences the dependent variable positively with exception to gender, education and role of respondents (on relevancy of information); gender and education (on medium of information); as well as gender and role on (cost of information). These findings imply that: there are no limitations whatsoever from SMEs to access international market information hence SMEs of any gender, age groups, education level, income and role can do that. Contrary, relevancy of the information and medium used to access that information, is negatively influenced by education level meaning with low financial education or skills SMEs may not be able to interpret some of the financial or market forecast or access more sophisticated medium of communications such as information communication and technology (ICT) mediated tools and equipments. On top of that, findings revealed that the ability to overcome high cost of information in the process of internationalization is highly influenced by both education and income of the SME's.

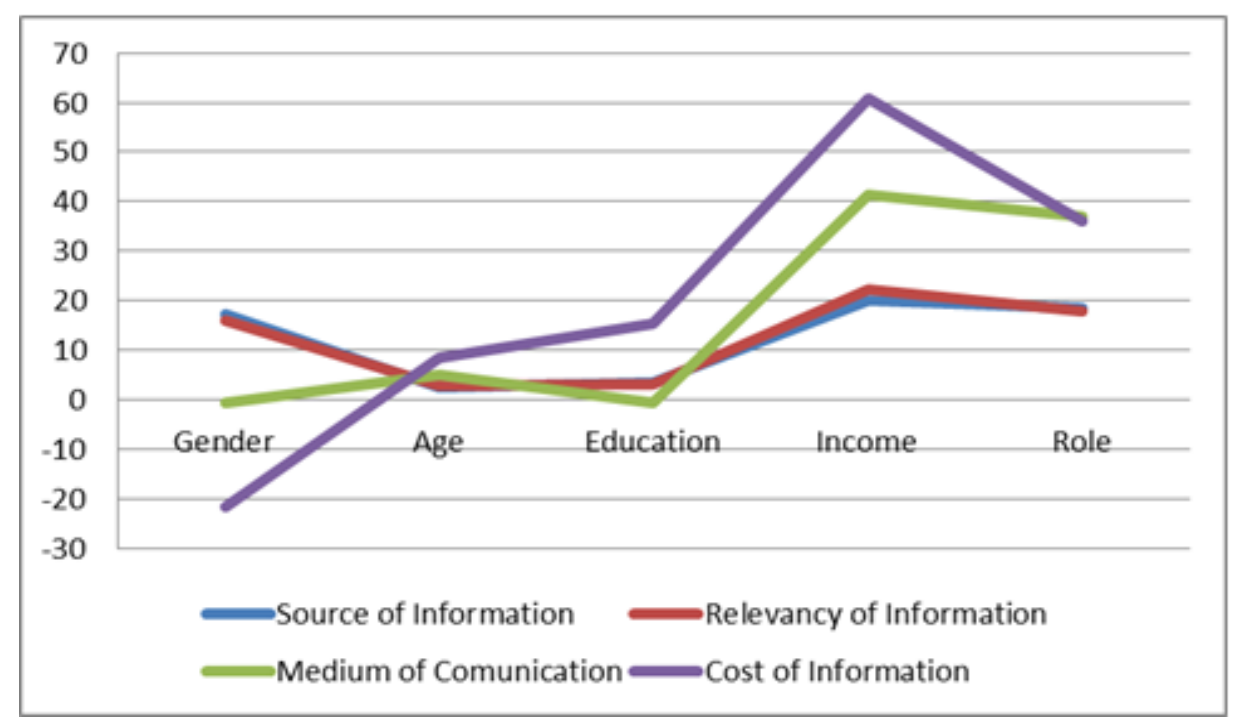

Source: Field data

Figure 2. Change of role of market information with respect to respondent's variables (in regression coefficient)

\subsubsection{The Contribution of Finance in the International Market}

The researcher found that, 78 percent of the respondent identified the finance being the major problem to take their goods to international markets. The internationalization process as explained in chapter one and two involves two major scenario's and at least four stages either produce at home and sell abroad or acquire firms abroad and produce. Only 22 percent disagree of the fact that finance is a problem to international market. In specific, this objective two was addressed through four financial areas which are: source of capital, collateral, credibility history and transaction cost. Specifically, the findings show that: 82 percent of respondent agree that source of capital is a major block to SME growth and business, 70 percent of SME lack collaterals to use as buffer for capital, 66 percent have no credibility 
history to support their needs of finance while 24 percent complain of the transaction costs for the finance they were to be given. Limited access to financial services mainly from formal financial institutions has also been identified as one of the serious obstacle facing SMEs towards meet their working and investment needs thus hindering their development as evidenced in Wang (2016), Kessy and Temu, (2010), Oketch (2000), Tomecko and Dondo (1992) .The findings on the degree of agreement of contribution of finance in international marketing are summarized in Figure 3.

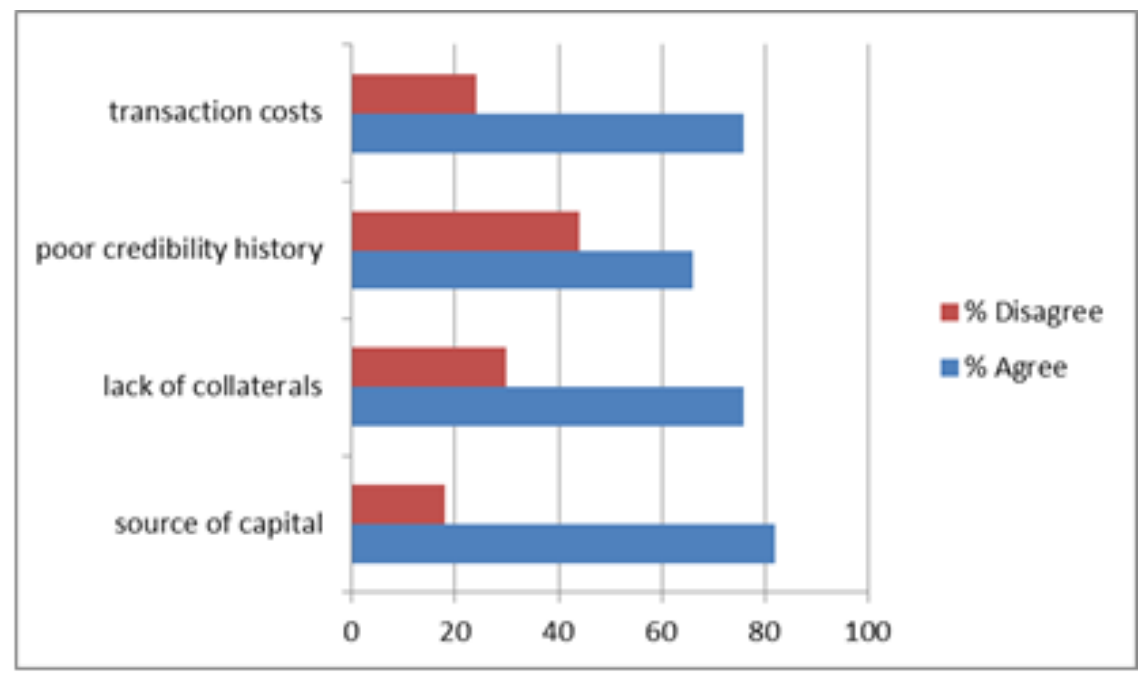

Source: Field data

Figure 3. Degree of agreement of contribution of finance in international market

In addition to the above output, study also carried out the binary logit regression analysis in order to foresee the likelihood that respondents would agree or disagree on the contribution of finance in the international market role of SMEs using the same predictor variables of age, gender, education, income and role. The results (Table 3) depicted that the percentage of correct prediction of variables ranges from 66 to 98 percent.Besides, the findings from the four models of finance challenge reveal that the predictor variables have ability to account for variability in the dependent variable by over 61 percent but less than 72.3 percent as shown by value of Cox \& Snell's R-square. On top of that, the findings from the chi square analysis show that all models for source of capital, lack of collateral, credibility history and transaction cost were statistically significant as shown by significant values of 0.000 which is less than p- value of 0.005 .

Table 3. Change of internationalization setback with regard to change in respondent variables

\begin{tabular}{|c|c|c|c|c|}
\hline \multicolumn{5}{|c|}{ Access to Finance } \\
\hline Variables & Capital & Collateral & Credibility History & Transaction Costs \\
\hline p-value & 0.00 & 0.00 & 0.00 & 0.00 \\
\hline $\mathrm{R}^{2}$ & $61.0 \%$ & $68.2 \%$ & $73.3 \%$ & $64.1 \%$ \\
\hline \multicolumn{5}{|c|}{ Regression coefficient $(\beta)$} \\
\hline Gender & -71 & -21.4 & -1.2 & -21.7 \\
\hline Age & -1.4 & 3.4 & 0.3 & 3.6 \\
\hline Education & 1.3 & 15.9 & -0.4 & 14.6 \\
\hline Income & 36.7 & 19.4 & 2.2 & 0.8 \\
\hline Role & 0.8 & -0.08 & -0.6 & 19 \\
\hline
\end{tabular}

Source: Field data

With regard to the change of the four financial variables with respect to the respondent's characteristics, the findings in Figure 4 show that with exception to gender, all respondents' characteristics affect the financial variables. Specifically, availability of capital was positively influenced by education level, income level and the role played by SME in international business implying that the more educated and income the more SME will have access to capital. On collateral, the findings revealed that the type and value of the collateral to be used by SMEs to secure finance for internationalization can be positively attributed by the age of the SME, level of education and income as well as the role someone play in the market. Besides, the findings in Figure 4 also depicted that credibility history is positively influenced by income and age in such that the more income one has the more credible he or she will be in the international market. On the other hand, the ability to overcome transaction costs has got nothing to do with gender of entrepreneurs within SME rather can be positively influenced by age, education, income and role played in the market. 
In general in order SMEs to access finance which will in turn contribute towards internationalization, efforts are required to improve business education level, income generated and involve more closely in the business.

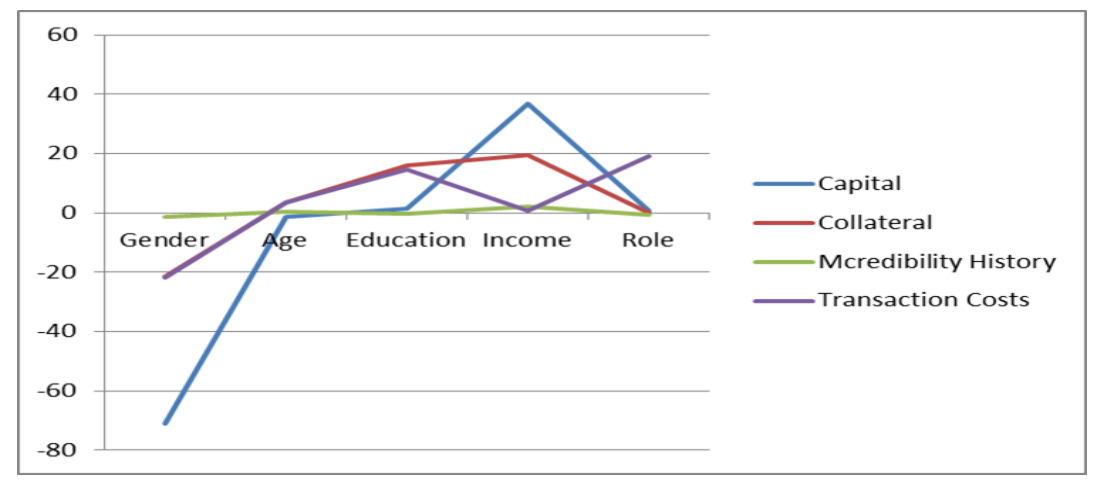

Source: Field data

Figure 4. Change of contribution of finance with respect to respondent's variables (in regression coefficient)

\subsubsection{The Impact of SME Quality of the Produce in International Market}

The aspect of SMEs quality was analyses using four sub variables namely as: selling semi processed product, poor finishing, packaging materials and processing machinery. The findings (Figure5) revealed that 62 percent of the respondent have agreed that the quality of SME produce in handcraft and tailoring are good and have quality to win the international market. When trading in international markets, countries benefit from higher product quality (Mody, Igan and Fabrizio, 2017). That's why the belief among the SME owners and employees to face challenges in survival to international is too positive. Only 38 percent are not happy to the quality of Arusha handcraft and tailoring products. Besides, the findings shows that the most quality aspects affecting international business are packaging materials for 72 percent and processing materials for 60 percent. Besides that, almost equal percentage had different opinion on poor finishing for 54 percent those who agree and 46 percent for those who disagree. In addition to that 52percent of respondents disagree on the quality aspect on selling semi processed product as challenge affecting international business for 52 percent,

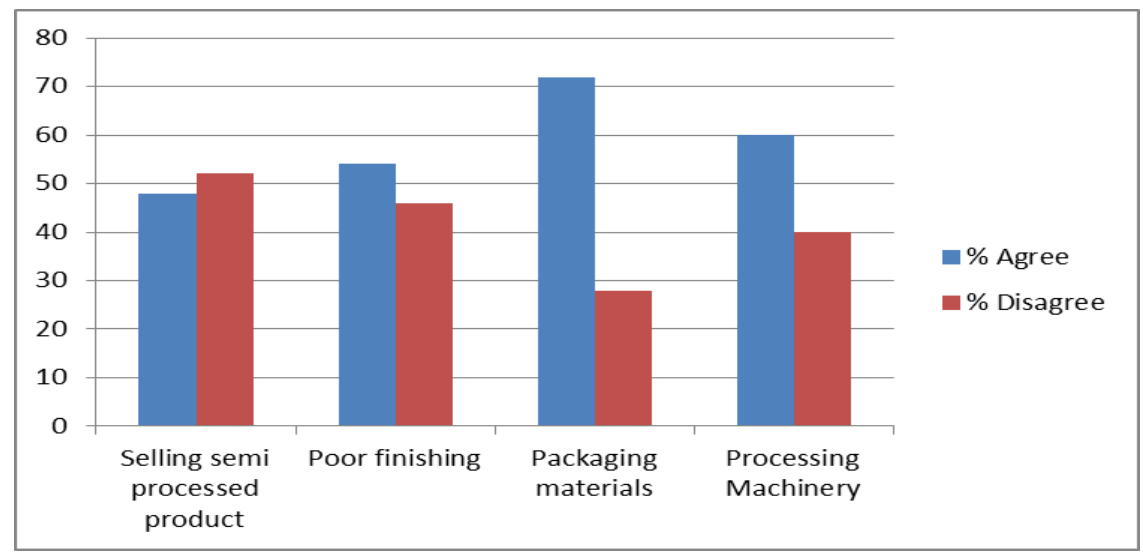

Source: Field data

Figure 5. Degree of agreement of the impact of quality in the success of international marketing

With regard to the inferential output for the impact of quality in the success of international market, the results from the binary logit regression (Table 4) depicted that the percentage of correct prediction of variables were 52, 54, 72 and 60 percent for selling semi processed product, poor finishing, packaging materials and processing machinery respectively. likewise the values of the obtained cox \& snell's r-square show that the ability to independent variables to account for variation in the dependent variable ranges from 67.3 to 75 percent. In addition to that, the findings from a computed chi-square statistic comparing the observed frequencies with those expected under the linear model shows significant as significant values for all four variables happened to be less that p- value i.e. 0.000 
Table 4. Change of internationalization setback with regard to change in respondent variables

\begin{tabular}{|c|c|c|c|c|}
\hline \multirow[b]{2}{*}{ Variables } & \multicolumn{3}{|c|}{ Quality of the product } & \multirow[b]{2}{*}{$\begin{array}{l}\text { Processing } \\
\text { Machinery }\end{array}$} \\
\hline & Selling semi processed product & $\begin{array}{l}\text { Poor } \\
\text { Finishing }\end{array}$ & $\begin{array}{l}\text { Packaging } \\
\text { Materials }\end{array}$ & \\
\hline $\mathrm{p}$-value & 0.00 & 0.00 & 0.00 & 0.00 \\
\hline $\mathrm{R}^{2}$ & $75.0 \%$ & $68.4 \%$ & $69.5 \%$ & $63.7 \%$ \\
\hline $\begin{array}{l}\text { Regression coefficient }(\beta) \\
\text { Gender }\end{array}$ & 2.8 & -16.4 & -3.7 & -17.7 \\
\hline Age & 2.9 & 2.5 & 3.2 & 2.3 \\
\hline Education & -4.9 & -3.6 & 34.3 & -2.5 \\
\hline Income & 0.3 & 18.9 & 1.3 & 20.4 \\
\hline Role & 38.9 & 19.5 & 0.1 & 18.1 \\
\hline
\end{tabular}

Source: Field data

Moreover, the change in impact of quality in relation to respondents variables Figure 6 revealed that selling semi processed product in internationalization is negatively affected by education in such that the lower the education on relationship between quality and price of the product in international market the higher the chance of SME's to sell semi processed and hence less competitive product.

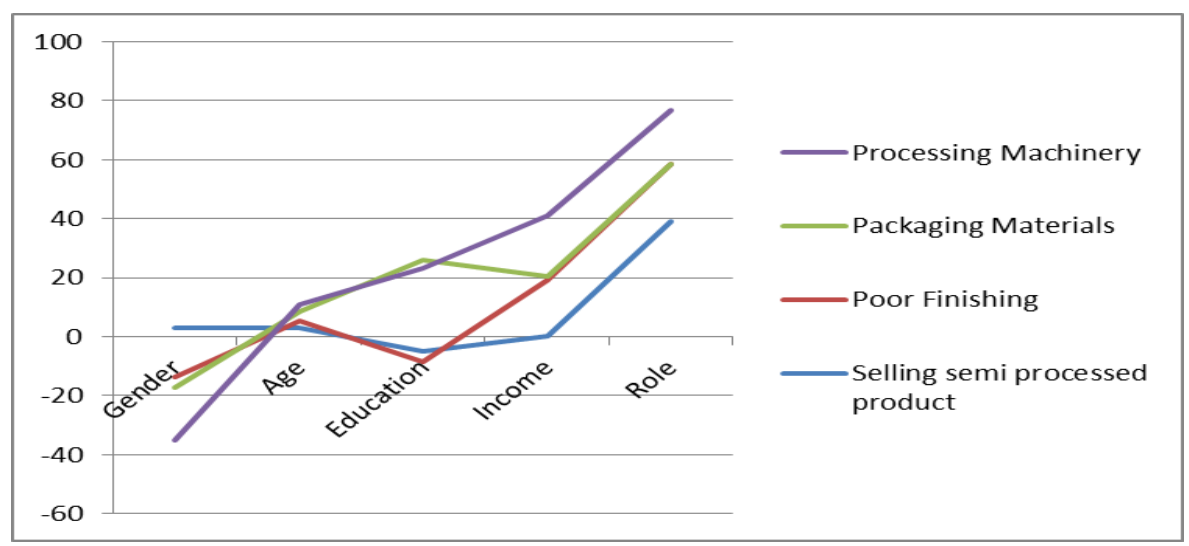

Source: Field data

Figure 6. Change of variables changes with respect the impact of quality in international market

Among the all respondents variable, income level to higher extent happened to affect poor finishing of the products, implying that good and quality products requires more money to perfect the products, thus for SMEs in Arusha, investing more money for quality finishing is inevitable. On top of that the findings revealed that both role and income affect highly positively on accessibility and availability of the processing machinery, thus the SMEs with high income have higher chance to afford sophisticated processing machinery for internationalization that those with low income level.

\section{Conclusions}

The research findings indicate that SME players in the market today are dominated by females about 62 percent and men 38 percent. Majority of them are aged between 36-45 years while their education is of primary $28 \%$ to $44 \%$ of the ordinary level Thus policy and structural efforts should be directed to support this group for the benefit of families and country's at large. Despite the fact that study finding revealed that only $38 \%$ of SME participate to international market, majority of people engaged in SME activities believe they have what it takes to be in the international arena if they can be well informed, financed and improved technology for their produce. The study tested the relevancy of information in international business and has proved that most SME fail to get the relevant market information due to affordability as costs of retrieving the information is high; furthermore, the information sources are not updated. Moreover the study found that the government has been willing to support the SME from the policy level, still supporting infrastructure needs some improvements to ensure things are moving as planned on the ground. Findings show that inspite of government support being 56 percent; still it has not been able to translate that support to SME operators. Most of the role played by the government has been to set good policies and organizations like SIDO, but is has failed to link directly the SME and their needs. With regard to transaction across the border, 60 percent of SME agreed that there is smooth passage of their products across borders on exit and entry points. This has been possible with the assistance TCCIA in issuing certificate of origin to SME who are going abroad to do business, however, quality related issues are 
still obstacles. The study also found 70 percent of SME have good and acceptable quality of handcrafts and tailoring produce but they lack exposure and guidance to penetrate and survive in international marketing as well as modern technologies for processing and packaging their product competitively.

Additionally, with regard to relationship between three assessed internationalization setbacks and respondents characteristics, the findings revealed that all SMEs regardless of their characteristics and status have ability to access international market information however the relevancy of the information and access more sophisticated medium of communications depend of education level. Also the ability to afford high cost of information is highly influenced income of the SME's .Pertaining to financial setbacks, the higher the education and income level the higher the chances of SMEs will to access to capital, and that credibility history is positively influenced by income since the more income SMEs have the more credible they will be towards internationalization. Therefore in order for SME to overcome financial setback, they must build their knowledge and capacity on business and marketing, raise more income to support their activities and play their active role all the time. On top of that, for product quality setbacks, it was established that good and quality products and availability of the processing machinery, requires more financial resources hence effort to provide supportive financial environment for SMEs is vital.

\section{Recommendations}

The study recommends the following:

On information perspective, SME owners aspire to get relevant information so as to sell full qualitative and quantitative handcraft and tailoring products to buyers in the market for better sales margin, sales growth and increase market share. However the SME owners need to invest in ICT and make use of website so as to have sufficient and updated information of the market they save. Kabanda and Brown (2017) depicted that websites are viewed primarily as a platform from which SMEs can portray a sophisticated image and advertise/market their products. SMEs use mobile technology extensively, as they draw on the technology's ability to offer transactive capability, mobility and communication. With regard to finance, SME owners are supposed to process and sell well finished handcraft and tailoring products. This means they have to conduct thorough research before committing their resources in the process. The research will need finance and above all they themselves need finance to save their firms. The finance is the key factor for their sustainable development and it is the competitive advantage to other players in the market local or international. The difficult and stringent financial rules from financial industry have been a huddle stone to firm's performance in either local or international market. SME must find a platform to speak out their needs and demands consultatively with the government as well as business supporting institutions such as Tanzania Chamber of Commerce Industry and Marketing (TCCIA), Tanzania Private Sector Foundation (TPSF).

With respect to handcrafts and tailoring, it was observed that the SME operators make little effort to advertise their products through international media. Hence there is a credible need to promote their products so to be seen by the buyers. This can be done individually as well as groups to cut down the advertisements cost. By so doing it will increases the business performance and business development economically because it will expose consumers to decide what and when to buy. Besides, the use of mobile phones for communication, open up special association/group website exposes business to buyers and other players globally which can lead to more opportunities. This will eventually support enterprises because more buyers will see available products and contact to buying or other networks. Above all, on government point of view, the authorities and policy makers should understand and incorporate the contribution the SME is plugging to GDP in line with planned support and developmental initiatives to them. The government should ensure the data bank of SMEs in the country is in place, negotiated the financing of SME by lowering the lending rate to the acceptable rates instead of letting private financial firms to lend them to the killing interest rates. Furthermore, regulation of quality standards must be well regulated because abased on Economic and Social Research Foundation (2016) quality standards control is inadequate in Tanzania and there is little capacity in the country to help enterprises to gain in competitiveness through ISO 9000 and ISO 14000 ratings of approval.

\section{References}

Ale, E. N., Ahmed, S., \& Taha, Z. (2009). Virtual R \& D teams in small and medium enterprises: A literature review. Scientific Research and Essay, 4(13), 1575-1590. Retrieved from: https://www.researchgate.net/publication/309240666

Anderson, W. (2011). Internationalization Opportunities and Challenges for Small and Medium-Sized Enterprises from Developing Countries, Journal of African Business, 12(2), 198-217. https://doi.org/10.1080/15228916.2011.588912

Caiazza, R. (2016) .Internationalization of SMEs in higher potential markets. Trends in Food Science \& Technology, 58, 127-132. https://doi.org/10.1016/j.tifs.2016.10.002 
Dominguez, N., \& Mayrhoefer, U. (2017). Internationalization stages of traditional SMEs: Increasing, decreasing and re-increasing commitment to foreign markets. International Business Review, 26(6), 1051-1063. https://doi.org/10.1016/j.ibusrev.2017.03.010

Economic and Social Research Foundation. (2016). Tanzania Country Update, Promoting the Participation of Small and Medium Enterprises (SMEs) in International Trade. Retrieved from http://esrf.or.tz/docs/EACGF7-Tanzania.pdf

Essays, UK. (November 2013). Current Status of SME Sector in Tanzania. Retrieved from http://www.ukessays.com/essays/economics/current-status-of-sme-sector-in-tanzania-economics-essay.php?vref=1

Hamisi, S. (2011). Challenges and opportunities of Tanzanian SMEs in adapting supply chain management African Journal of Business Management, 5(4), 1266-1276. Retrieved from http://www.academicjournals.org/AJBM DOI: 10.5897/AJBM10.704 ISSN 1993-8233

Harmon, R. (2003). Marketing Information Systems. Encyclopedia of Information Systems, Elsevier Science (USA), 3, 137-151. https://doi.org/10.1016/B0-12-227240-4/00110-6

Ishengoma, E. K. (2018). Entrepreneur Attributes and Formalization of Micro, Small and Medium Enterprises in Tanzania, Journal of African Business. https://doi.org/10.1080/15228916.2018.1472480

Justin, P., Sundar, P., \& Parul, G. (2017). Exporting challenges of SMEs: A review and future research agenda. Journal of World Business, 52(3), 327-342. https://doi.org/10.1016/j.jwb.2017.01.003

Kabanda, S., \& Brown, I. (2017). A structuration analysis of Small and Medium Enterprise (SME) adoption of E-Commerce: The case of Tanzania. Telematics and Informatics, 34(4), 118-132. https://doi.org/10.1016/j.tele.2017.01.002

Kalantone, C., \& Knight, G. (2000). The Critical Role of Product Quality in the International Performance of Industrial Firms. Industrial Marketing Management, 29(6), 493-506. https://doi.org/10.1016/S0019-8501 (00)00124-3

Kazimoto, P. (2014). Assessment of Challenges facing Small and Medium Enterprises towards International Marketing Standards: a Case Study of Arusha Region Tanzania international Journal of Academic Research in Accounting, Finance and Management Sciences, 4(2), 303-311DOI: 10.6007/IJARAFMS/v4-i2/893URL: http://dx.doi.org/10.6007/IJARAFMS/v4-i2/893.

Kessy, S., \& Temu, S. S. (2010). The Impact of Training on Performance of Micro and Small Enterprises Served by Microfinance Institutions in Tanzania. Research Journal of Business Management, 4, $103-111$. https://doi.org/10.3923/rjbm.2010.103.111

Kotler, P., \& Keller, K. L. (2006). Marketing Management (12 ed.). Pearson Education.

Mody, A., Igan, D., \& Fabrizio, S. (2017). The Dynamics of Product Quality and International Competitiveness. IMF Working Papers. Retrieved from https://www.imf.org/en/Publications/WP/Issues/2016/12/31/The-Dynamics-of-Product-Quality-and-InternationalCompetitiveness-20647

Mpunga, S. (2016). Examining the Factors Affecting Export Performance for Small and Medium Enterprises (SMEs) in Tanzania Journal of Economics and Sustainable Development, 7(6), 201641.

Oketch, H. O. (2000). Gender equity. In A.Mullie and Bokea (Eds). Micro and Small Enterprises in Kenya: Agenda for improving the policy Environment. Nairobi. ICEG

Örberg, J. P. D. (2009). A learning perspective on the offshoring of advanced services. Journal of international management, 181-193.

Poole, D. (2008). Entrepreneurs, entrepreneurship and SMEs in developing economies: How subverting terminology sustains flawed policy. World Development Perspectives, 9, 35-42. https://doi.org/10.1016/j.wdp.2018.04.003

Rutashobya, L. \& Jaensson, J. (2004). Small firms' internationalization for development in in Tanzania: Exploring the network phenomenon. International Journal of Social Economics, 31(1/2), 159-172. https://doi.org/10.1108/03068290410515484

Saunders, M., Lewis, P., \& Thornhill, A. (2012). Research Methods for Business Students. 6th edition, Pearson Education Limited

Singh, M. (2013). Product Quality for Competitive Advantage in Marketing. International Journal of Business and Management Invention, 2(6), 05-08

Sitorus, D. (2017). Improving access to finance for SMEs in Tanzania: Learning from Malaysia's experience .The world 
Bank. Retrieved from pacific/improving-access-finance-smes-tanzania-learning-malaysia-s-experience

Tanzania Invest. (2018) .Tanzania Small and Medium Enterprises. Retrieved from https://www.tanzaniainvest.com/sme Temecko. J., \& Dondo, A. (1992). Improving the potential of small scale and informal sector Nairobi: K-REP and GTZ

The World Bank. (2018). The World Bank in Tanzania. Retrieved from www.worldbank.org/en/country/tanzania/overview

United Republic of Tanzania (URT) Ministry of Finance. (2018). The Tanzania Development Vision 2025. Retrieved from www.mof.go.tz/mofdocs/overarch/vision2025.htm

United Republic of Tanzania (URT) Ministry of Industry and Trade. (2003).SME development policy.Dar es Salaam, Tanzania: Government printer

United Republic of Tanzania. (URT) Planning Commission Dar es Salaam and Regional Commissioner's Office Arusha (1998). Arusha Region Socio-Economic Profile. Retrieved from http://www.tzonline.org/pdf/Arusha.pdf.

Wang, Y. (2016). What are the biggest obstacles to growth of SMEs in developing countries? - An empirical evidence from an enterprise survey. Borsa Istanbul Review, 16(3), 167-176. https://doi.org/10.1016/j.bir.2016.06.001

World Trade Organization-WTO. (2016). Trade Finance and SME: Bridging the gaps in provision. Retrieved from https://www.wto.org/english/res_e/booksp_e/tradefinsme_e.pdf retrieved on 26 April 2017

\section{Copyrights}

Copyright for this article is retained by the author(s), with first publication rights granted to the journal.

This is an open-access article distributed under the terms and conditions of the Creative Commons Attribution license which permits unrestricted use, distribution, and reproduction in any medium, provided the original work is properly cited. 